\title{
Bioremoval of Different Heavy Metals by the Resistant Fungal Strain Aspergillus niger
}

\author{
Ismael Acosta-Rodríguez (iD, ${ }^{1}$ Juan F. Cárdenas-González, ${ }^{2}$ Adriana S. Rodríguez Pérez, ${ }^{2}$ \\ Juana Tovar Oviedo, ${ }^{1}$ and Víctor M. Martínez-Juárez ${ }^{3}$ \\ ${ }^{1}$ Universidad Autónoma de San Luis Potosí, Facultad de Ciencias Químicas, Centro de Investigación y de Estudios de Posgrado, \\ Laboratorio de Micología Experimental, Av. Dr. Manuel Nava No. 6, Zona Universitaria, C.P. 78320, San Luis Potosí, Mexico \\ ${ }^{2}$ Unidad Académica Multidisciplinaria Zona Media, Universidad Autónoma de San Luis Potosí, \\ Carretera San Ciro de Acosta Km. 4, Ejido Puente del Carmen. C.P. 79617, Río Verde, \\ San Luis Potosí, Mexico \\ ${ }^{3}$ Área Académica de Medicina Veterinaria y Zootecnia, Instituto de Ciencias Agropecuarias, \\ Universidad Autónoma Del Estado de Hidalgo, Zona Universitaria, Rancho Universitario Km 1. C.P. 43600, \\ Tulancingo de Bravo Hidalgo, Mexico \\ Correspondence should be addressed to Ismael Acosta-Rodríguez; iacosta@uaslp.mx
}

Received 21 June 2018; Revised 24 August 2018; Accepted 13 September 2018; Published 1 November 2018

Guest Editor: Raja Sulaiman Azarudeen

Copyright (c) 2018 Ismael Acosta-Rodríguez et al. This is an open access article distributed under the Creative Commons Attribution License, which permits unrestricted use, distribution, and reproduction in any medium, provided the original work is properly cited.

\begin{abstract}
The objective of this work was to study the resistance and removal capacity of heavy metals by the fungus Aspergillus niger. We analyzed the resistance to some heavy metals by dry weight and plate: the fungus grew in $2000 \mathrm{ppm}$ of zinc, lead, and mercury, 1200 and $1000 \mathrm{ppm}$ of arsenic (III) and (VI), $800 \mathrm{ppm}$ of fluor and cobalt, and least in cadmium (400 ppm). With respect to their potential of removal of heavy metals, this removal was achieved for zinc (100\%), mercury (83.2\%), fluor (83\%), cobalt (71.4\%), fairly silver (48\%), and copper (37\%). The ideal conditions for the removal of $100 \mathrm{mg} / \mathrm{L}$ of the heavy metals were $28^{\circ} \mathrm{C}$, pH between 4.0 and $5.5,100 \mathrm{ppm}$ of heavy metal, and $1 \mathrm{~g}$ of fungal biomass.
\end{abstract}

\section{Introduction}

Heavy metals are ubiquitous contaminants that have accompanied the man from the earliest ancient times, and unlike other environmental pollutants, heavy metals are chemical elements that man does not create or destroy. The role that man plays in the environmental presence of metals is to introduce into the environment these elements as a result of different human activities, and on the other hand, to alter the chemical or biochemical form in which they are. Metals are naturally subjected to biogeochemical cycles that determine their presence and concentration in different natural environments such as soil, groundwater and surface, air, and living beings. Human intervention can greatly modify the concentration of metals in these environments and facilitate their distribution from the mineral reserves in which metals are naturally confined [1]. From the toxicological point of view, metals often present a marked multiplicity of toxic effects. The specific chemical species of the metal strongly influences these effects, as well as the toxicokinetic variables of absorption, distribution, and excretion. The toxicological significance of heavy metals, taking into account their ubiquity, the extent of their industrial and domestic uses, as well as their environmental persistence, which has to be evaluated based on the characteristics of the chemical compound of which the metal is part, and which determine its mobility environmental and its bioavailability [2].

In Mexico, there are reports of the presence of heavy metals in rivers, lakes, crops, soils, and air urban areas, as well as in coastal environments and marine ecosystems, where the accumulation of toxic metals in fish and shellfish 
tissues of human consumption is seen [3, 4], and mining is one of the main causes of environmental pollution by heavy metals, mainly due to the inadequate management of their so-called mine tailings. There are reports of widespread contamination in states of the Mexican Republic such as Zacatecas, San Luis Potosí, Guerrero, and Sonora. [4-6]. Reports indicate that in Mexico there could be million tons of pull at the national level, of which they are still unknown the conditions and their potential to affect the environment $[1,7]$. The most common example is the soil contamination, which occurs during the extraction of gold and silver, commonly made by amalgamation with mercury and cyanidation. In neither case, there is a total recovery of the compounds or added elements, so it is common to find them in the process residues (mining sludges) in the soluble form $[1,4,7]$, so that, the "tailings" contain a great quantity of residual metals that derive from a process of extraction that is not $100 \%$ efficient, so they exceed the maximum permissible limits of these metals for soils and waters in Mexico, established in the NOM-147-SEMARNAT/SSA1-2004 [8] and NOM-001-SEMARNAT-1996 [9], respectively. In humans, heavy metals can become very toxic when introduced into the organism. At high concentrations, these can cause skin rashes, stomach upset (ulcers), respiratory problems, weakening of the immune system, damage to the kidneys and liver, hypertension, alteration of genetic material, cancer, neurological disorders, and even death [10]. Despite existing legislation on disposal and waste management, it is clear that the problem persists. The foregoing, together with the waste from mining, aggravates the situation of the contamination by heavy metals in Mexico. Different public institutions have developed investigations to establish the magnitude of this problem and have proposed strategies to contribute to the solution of the same, focusing on the use of biological alternatives that result in a lower alteration of the environment, specifically through the use of microorganisms for the removal of heavy metals or biosorption [11]. There are many reports of the isolation of resistant microorganisms to heavy metals and the use of microbial biomass for the removal of heavy metals, from industrial wastewater and/or contaminated water: the resistance and removal of Rhizopus stolonifer to lead, cadmium, copper, and zinc [11], the tolerance and removal mechanisms of heavy metals (lead, cadmium, and chromium), by the fungus Pleurotus ostreatus HAAS [12], Bacillus megaterium nickel resistance and her capacity of removal [13], heavy metal susceptibility and removal potential (mercury, copper, and lead) of Rhodotorula mucilaginosa [14], the resistance of Alcaligenes sp. BAPb.1 to lead (II), copper (II), zinc (II), nickel (II), and chromium (VI), and his capacity for removal of lead (II) [15], the isolation and identification of fungi and yeast resistant to lead (II) [16], the resistance and removal of chromium (VI) by Aspergillus niger [17], the removal of different heavy metals by $A$. niger [18], the removal of lead, cadmium, copper, and nickel by $A$. niger [19], the removal of aluminum, iron, lead, and zinc by $A$. niger during the bioleaching process [12], and the removal of copper (II), manganese (II), zinc (II), nickel (II), iron (III), lead (II), and cadmium (II) by immobilized cells of A. niger [20], with highly satisfactory results. This work reports the removal of different heavy metal in an aqueous solution by a strain of $A$. niger which is highly resistant to some heavy metals.

\section{Experimental}

2.1. Microorganisms and Heavy Metals Resistant Tests. The fungal strain of $A$. niger was isolated from the polluted air in a fuel station, near to the Faculty of Chemical Science, belonging to the Autonomous University of San Luis Potosí (San Luis Potosi, Mexico) [17], and this was used for the screening. In addition to the above, this fungus was conditioned for years under conditions of biological stress and was inoculated in culture media containing between 0 and $500 \mathrm{ppm}$ of different heavy metals such as chromium, lead, cadmium, arsenic, etc. For the isolation, growth, and $\mathrm{pH}$ calibration, we carried out the methodology of AcostaRodríguez et al. [21] as follows: on Petri dishes containing modified Lee's minimal medium (LMM) (with 0.25\% $\mathrm{KH}_{2} \mathrm{PO}_{4}, 0.20 \% \mathrm{MgSO}_{4}, 0.50 \%\left(\mathrm{NH}_{4}\right)_{2} \mathrm{SO}_{4}, 0.50 \% \mathrm{NaCl}$, $0.25 \%$ glucose, and $2 \%$ agar) supplemented with $500 \mathrm{mg} / \mathrm{L}$ of $\mathrm{K}_{2} \mathrm{CrO}_{4}$. The $\mathrm{pH}$ of the medium was adjusted with a $\mathrm{pH}$ meter Corning Pinnacle 540 and maintained at 5.3 with $100 \mathrm{mmol} / \mathrm{L}$ of citrate phosphate buffer. The plates were incubated at $28^{\circ} \mathrm{C}$ for 7 days. Fungal cultures grown in thioglycolate broth were used as primary inoculums. Heavy metals resistant tests of the isolated strain, the fungi A. niger, were performed on liquid LMM containing the appropriate nutritional requirements and different concentrations of heavy metals (as salt), and the dry weight was determined.

2.2. Heavy Metal Resistance Assay. For the resistance test, we followed the methods of Acosta-Rodríguez et al. [21], where Petri dishes were prepared with Sabouraud Dextrose Agar, added with different heavy metals salts. The prepared plates were inoculated with $1 \times 10^{6}$ spores $/ \mathrm{mL}$, uniformly spread throughout the dishes, and incubated at $28^{\circ} \mathrm{C}$ for 7 days, and the growth of the plates was compared with a control.

2.3. Obtaining the Fungal Biomass. For their propagation, $1000 \mathrm{~mL}$ Erlenmeyer flasks containing $600 \mathrm{~mL}$ of thioglycolate broth $(8 \mathrm{~g} / \mathrm{L})$ were used. The prepared flasks were inoculated with $1 \times 10^{6}$ spores $/ \mathrm{mL}$ and were incubated at $28^{\circ} \mathrm{C}$, with constant stirring $(100 \mathrm{rpm})$ [21]. After 5 days of incubation, the cells were filtered in Whatman paper No. 1, washed twice with trideionized water, and then dried at $80^{\circ} \mathrm{C}$ for $12 \mathrm{~h}$ in an oven. Finally, the fungal biomass was milled and stored in an amber bottle at room temperature until their use.

2.4. Preparation of Iron Oxide-Coated Biomass. $80 \mathrm{~mL}$ of $2 \mathrm{M}$ $\mathrm{Fe}\left(\mathrm{NO}_{3}\right)_{3} \cdot 9 \mathrm{H}_{2} \mathrm{O}$ was prepared and $1.0 \mathrm{~mL}$ of $10 \mathrm{M} \cdot \mathrm{NaOH}$ was added to this solution and mixed thoroughly. $20 \mathrm{~g}$ of the fungal biomass powder was taken in a porcelain pot, and a mixture of iron oxide and $\mathrm{NaOH}$ solution was added to the porcelain pot and homogenized, kept in an oven for $3 \mathrm{~h}$ at $80^{\circ} \mathrm{C}$. Afterwards, the oven temperature was raised to $110^{\circ} \mathrm{C}$ and continued for $24 \mathrm{~h}$. The coated biomass powder was separated by crushing with mortar and pestle [22]. 
2.5. Biosorption Tests for Heavy Metals by Fungal dry Cells. Solutions of heavy metals for analysis were prepared by diluting $1 \mathrm{~g} / \mathrm{L}$ of stock metal solution. The concentration range of heavy metals solutions was $1-100 \mathrm{mg} / \mathrm{L}$. The $\mathrm{pH}$ of each solution was adjusted to the required value by adding $1 \mathrm{M} \cdot \mathrm{H}_{2} \mathrm{SO}_{4}$ solution before mixing with the fungus with an analyzer Corning Pinnacle 540. The biosorption of the metals by fungal dry cells was determined at different concentrations of $100 \mathrm{~mL}$ heavy metal solution, with $1 \mathrm{~g}$ of fungal biomass, at $100 \mathrm{rpm}$, and the sample was filtered, and the supernatant was analyzed for residual heavy metals at different times after a contact period: zinc (II), lead (II), mercury (II), cadmium (II), spectrophotometrically with a Genesys 10S Vis and the dithizone method [23], cobalt (II) by methyl isobutyl ketone [24], fluorine (I) by specific ion, and copper (II), arsenic (III), arsenic (V), and silver (I), by atomic absorption with spectrophotometer Varian SpectrAA 220 [25]. Moreover, biosorption to the contaminated water was examined. To six Erlenmeyer glass flasks add $5 \mathrm{~g}$ of fungal biomass and $95 \mathrm{~mL}$ of water $(263 \mathrm{mg} / \mathrm{L}$ of lead (II), $183 \mathrm{mg} / \mathrm{L}$ of Mercury (II), and $250 \mathrm{mg} / \mathrm{L}$ of cobalt (II)), from the farmland of the "Tanque Tenorio" (which is southeast of the city, in the municipality of Soledad de Graciano Sánchez, S.L.P., Mexico, and is a catchment lagoon of wastewater, of which $60 \%$ and $40 \%$ are from urban and industrial origin, respectively) (it should be noted that the industrial zone of San Luis Potosí has more than 520 companies, among which are the mining-metallurgists, textiles, and chemicals) [25], and they were incubated during 7 days, stirred at $100 \mathrm{rpm}$, and filtered in Whatman filter paper No. 1, and the concentration of lead (II), Mercury (II), and zinc (II) of the filtrate was analyzed.

\section{Results and Discussion}

3.1. Isolation and Identification of a Fungal Strain Resistant to Heavy Metals. The fungal strain was kept in culture medium like LMM containing different concentrations of heavy metals for many years, which caused mechanisms of adaptation and resistance to these metals, causing the fungus to not die intoxicated and could remove several of them. This indicates that these fungi developed the heavy metal tolerance and/or resistance, and they were identified by their macroscopic and microscopic characteristics [26]. In a previous study, it has been reported that the fungus grew in $2000 \mathrm{mg} / \mathrm{L}$ ( $42 \mu \mathrm{g}$ of dry weight) of chromium (VI), and it presents very good adsorption capacity of chromium (VI) in different conditions [17]. Also, the strain grew on LMM supplemented with different concentrations of heavy metals, about $37.6 \%, 24.6 \%$, and $13.5 \%$, of zinc (II), mercury (II), and lead (II), respectively, of growth relative to control without metal, and, therefore, probably is resistant to the metals, although, it grew a $16 \%$ with $1.4 \mathrm{~g} / \mathrm{L}$ of arsenic (III), and it is very sensitive to cobalt (II) $(12.8 \%$ with $600 \mathrm{mg} / \mathrm{L})$ (Figure 1). On the other hand, in plate-resistant testing, the fungus grows in $2000 \mathrm{mg} / \mathrm{L}$ of zinc (II), lead (II), mercury (II), and chromium (VI), $1200 \mathrm{~g} / \mathrm{L}$ of Arsenic (III), $600 \mathrm{mg} / \mathrm{L}$ of cobalt (II), and $400 \mathrm{mg} / \mathrm{L}$ of cadmium (II) (Table 1), showing that the fungus has the ability to grow at very high concentrations of these different toxic metals, and it can present different mechanisms of resistance and/or adaptation to toxic metals.

Different microorganisms that are heavy metals resistant have been isolated from different contaminated sites: screening the resistance to lead, cadmium, copper, and zinc of five fungal species isolated from soils: Emericella quadrilineata, A. niger, Macrophomina phaseolina, R. stolonifer, and Aspergillus fumigatus, and the most resistant fungal species $(1 \mathrm{~g} / \mathrm{L}$ of metals) was $R$. stolonifer followed by $M$. phaseolina which showed resistance with all the metals, while $A$. niger, A. fumigatus, and E. quadrilineata were more sensitive to these heavy metals [11], the fungus $P$. ostreatus HAAS grew very well in $500 \mathrm{mg} / \mathrm{L}$ of lead, and concentrations of $30 \mathrm{mg} / \mathrm{L}$ of cadmium and $200 \mathrm{mg} / \mathrm{L}$ of chromium appeared to inhibit the growth of the fungus [12], B. megaterium strain MNSH1-9K-1 tolerate up to $200 \mathrm{ppm}$ of each nickel and vanadium [13], Alcaligenes sp. BAPb.1, grow in the presence of $1000 \mathrm{mg} / \mathrm{L}$ of lead (II), $600 \mathrm{mg} / \mathrm{L}$ of copper (II), $600 \mathrm{mg} / \mathrm{L}$ of zinc (II), $400 \mathrm{mg} / \mathrm{L}$ of nickel (II) and chromium(VI) [15], Penicillium sp., Trichoderma sp., and Alternaria sp., isolated from the farmland of the "Tanque Tenorio", grow with 500-2000 mg/L of lead (II) [16], A. niger has been growing in the presence of different concentrations of metals like nickel, cobalt, iron, magnesium, and manganese [27], and the yeast Candida tropicalis, isolated from wastewater from industrial area of Sheikhupura, which is grown in $2.5 \mathrm{~g} / \mathrm{L}$ of cadmium (II), zinc (II) $(1.4 \mathrm{~g} / \mathrm{L})$, nickel (II) $(1 \mathrm{~g} / \mathrm{L})$, Mercury (II) $(1.4 \mathrm{~g} / \mathrm{L})$, copper (II) (1 g/L), chromium (VI) (1.2 g/L), and lead (II) (1 g/L) [28].

3.2. Removal of Different Heavy Metals by Fungal Biomass of A. niger. On the other hand, we analyzed the capacity of heavy metals removal by dry cell of the fungus. The results are shown in Table 2 . The fungus removed efficiently most of the heavy metals analyzed: zinc (II) (100\%), mercury (II) (83.2\%), fluor (I) (83\%), and cobalt (II) $(71.4 \%)$, and less efficiently: silver (I) (48\%) and copper (37\%). Dead fungal cells can be effective metal accumulators, and there is evidence that some biomass-based cleanup processes are economically viable $[2,4]$. The tolerance of some fungal species to heavy metals, as well as the physiological response to them, has been also determined [2,11-13]. The removal of heavy metal ions, using fungus as biosorbents, was previously investigated $[2,4,12,17-20]$. Our results confirm the capacity of the microorganisms biomass for the removal of heavy metals with different effectivity, like bacteria, fungus, yeast, and algae-based microbiological decontamination of heavy metals contaminated soils of different places [2-5]: $M$. phaseolina and $R$. stolonifer for the removal of lead, cadmium, copper, and zinc, from soil [11], the removal of lead, cadmium, and chromium, in liquid culture with P. ostreatus HAAS [12], the removal of lead, cadmium, copper, and nickel, with A. niger [19], the elimination of copper, cadmium, lead, and zinc in dried soil residues with $A$. niger during the bioleaching process [12], the removal of copper (II) and cadmium (II) in batch systems by immobilized cells of A. niger [20], the removal of $90 \%$ of chromium (VI) by 


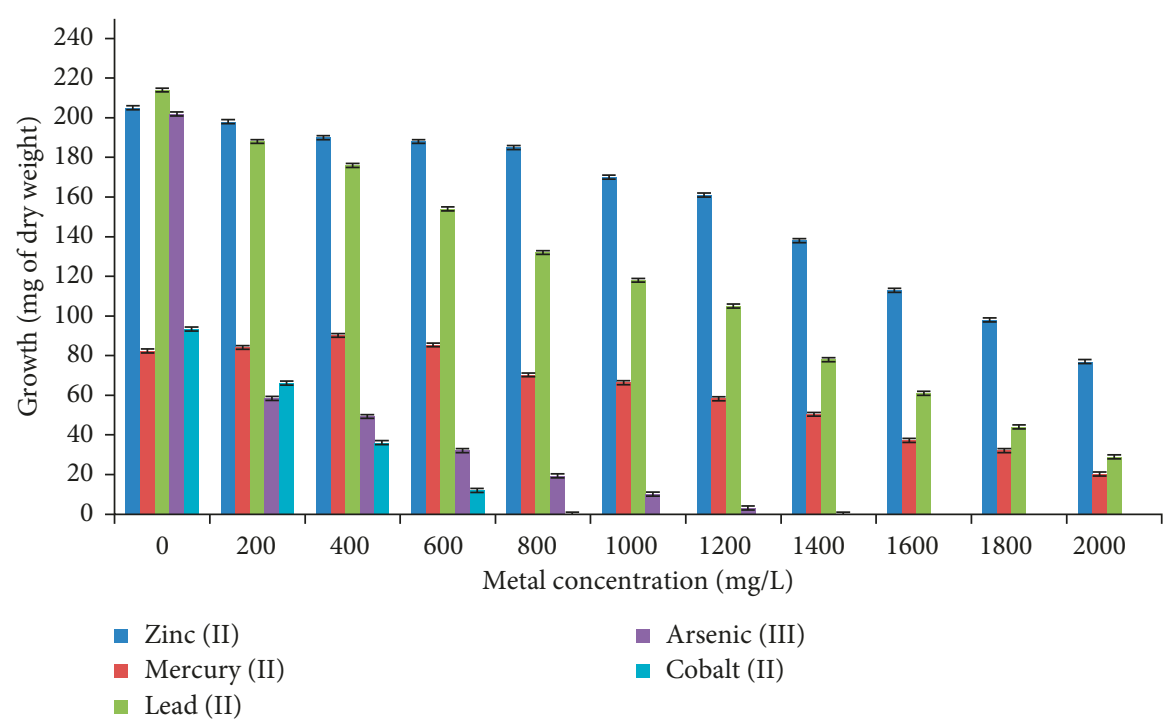

Figure 1: Growth in dry weight of Aspergillus niger with different heavy metals concentrations: $1 \times 10^{6}$ spores $/ \mathrm{mL} ; 28^{\circ} \mathrm{C}, 7$ days of incubation; $100 \mathrm{rpm}$.

TABLE 1: Growth in LMM in plate of Aspergillus niger with different heavy metals: $1 \times 10^{6}$ yeast $/ \mathrm{mL}, 28^{\circ} \mathrm{C}$, and 7 days of incubation.

\begin{tabular}{lc}
\hline Heavy metal & $\begin{array}{c}\text { Growth } \\
\text { Heavy metal } \\
\text { concentration (mg/L) }\end{array}$ \\
\hline Zinc (II) & 2000 \\
Lead (II) & 2000 \\
Mercury (II) & 2000 \\
Chromium (VI) & 2000 \\
Arsenic (III) & 1200 \\
Arsenic (V) & 1000 \\
Copper & 1000 \\
Silver & 1000 \\
Fluor & 800 \\
Cobalt & 600 \\
Cadmium & 400 \\
\hline
\end{tabular}

$\mathrm{NaOH}$-pretreated $A$. niger biomass, and that heavy metal uptake by live $A$. niger biomass for cadmium (II) and for zinc (II) [29], yeasts isolated from water, soil, and plant environments [30], and other studies with other species of fungi $[4,18,19,31-34]$. According to our results, we can assume the surface of the biomass coated with iron oxide is partially ionized, causing the $\mathrm{pH}$ to approach neutrality; apparently, the $\mathrm{OH}^{-}$groups present compete for the binding sites with the heavy metals and the biomass, decreasing the removal of metals, while at acid $\mathrm{pH}$, there is a better removal of the heavy metals [35].

\subsection{Removal of Heavy Metals in Industrial Wastes with Fungal} Biomass. For analyzing the possible use and the ability of A. niger biomass to removal of lead (II), cobalt (II), and mercury (II), from wastewater, a removal assay was mounted in an aqueous solution in the presence of $5 \mathrm{~g}$ biomass, with $95 \mathrm{~mL}$ of nonsterile water contaminated (from “Tanque Tenorio") with $263 \mathrm{mg} / \mathrm{L}$ of lead (II), $183 \mathrm{mg} / \mathrm{L}$ of mercury (II), and $250 \mathrm{mg} / \mathrm{L}$ of cobalt (II), at
TABLE 2: Removal of different heavy metals by fungal biomass of A. niger: $28^{\circ} \mathrm{C}, 1 \mathrm{~g}$ of fungal biomass, $100 \mathrm{rpm}, 24 \mathrm{~h}$.

\begin{tabular}{lccc}
\hline Heavy metals & $\mathrm{pH}$ & $\begin{array}{c}\text { Initial concentration } \\
(\mathrm{mg} / \mathrm{L})\end{array}$ & \% removal \\
\hline Chromium (VI) & 1.0 & 50 & $100^{*}$ \\
Zinc (II) & 5.0 & 100 & $100^{* *}$ \\
Mercury (II) & 5.5 & 100 & 83.2 \\
Fluor (I) & 6.0 & 10 & 83.0 \\
Cobalt (II) & 5.0 & 100 & 71.4 \\
Arsenic (V) & 6.0 & 1.0 & $69^{* * *}$ \\
Arsenic (III) & 6.0 & 1.0 & $66^{* * *}$ \\
Lead (II) & 4.0 & 100 & 59.0 \\
Cadmium (II) & 6.0 & 5.0 & 57.0 \\
Silver (I) & 6.0 & 100 & 48.0 \\
Copper (I) & 5.0 & 100 & 37.0 \\
\hline
\end{tabular}

${ }^{*} 30$ minutes [17]. ${ }^{* *} 165$ minutes. ${ }^{* * *}$ Fungal biomass modified with $\mathrm{Fe}$ $\left(\mathrm{NO}_{3}\right)_{3} \cdot 9 \mathrm{H}_{2} \mathrm{O}$.

$\mathrm{pH} 5.0$ (adjusted), $28^{\circ} \mathrm{C}$ and stirring at $100 \mathrm{rpm}$. It was observed that at 7 days of incubation, $71 \%, 69 \%$, and $96.4 \%$, of the heavy metals present in the water contaminated were removal, respectively (Figure 2). The metal removal capability by the biomass of $A$. niger is equal to or greater than the other biomasses that have been studied, like the removal of mercury, cadmium, an copper $(4.79 \%$, $10.25 \%$, and $5.49 \%$, respectively), using $R$. mucilaginosa planktonic cells during 48 hours [17], the metal removals during two-step process using $A$. niger reached $84.3 \%, 84.4 \%$, $25 \%$, and $14.4 \%$ for copper, cadmium, lead, and zinc, respectively [12], the removal of cadmium (II) (95\%), lead (II) (88\%), iron (III) (70\%), copper (II) (60\%), nickel (II) (48.9\%), manganese (II) (37.7\%), and zinc (II) (15.4\%), from industrial wastewater in batch systems by immobilized cells of A. niger [20], the use of the extracellular media of Alternaria alternata-containing organic acids and siderophores for the metal leaching (vanadium, aluminum, molybdenum, magnesium, iron, nickel, arsenic, and chromium) [32], the 


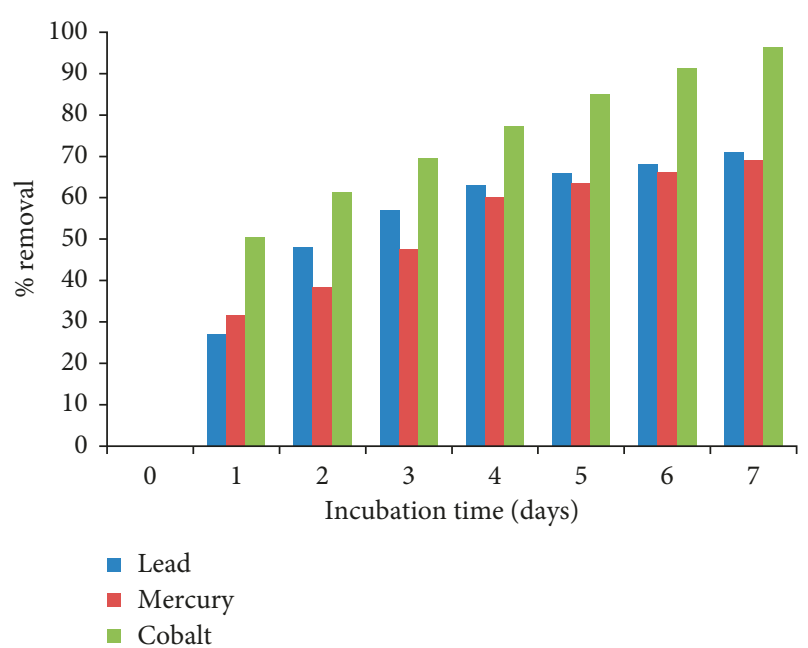

Figure 2: Removal of heavy metals from industrial wastes incubated with $5 \mathrm{~g}$ of fungal biomass and $95 \mathrm{~mL}$ of water contaminated with $263 \mathrm{mg} / \mathrm{L}$ of lead (II), $183 \mathrm{mg} / \mathrm{L}$ of mercury (II), and $250 \mathrm{mg} / \mathrm{L}$ of cobalt (II), at pH 5.0 (adjusted), $28^{\circ} \mathrm{C}$, and $100 \mathrm{rpm}$.

removal of $67 \%$ of arsenic (III) from samples of groundwater contaminated with $1 \mathrm{mg} / \mathrm{L}$ from the metalloid, coming from Zimapan, Hidalgo's state, Mexico [36], the 99.35\% removal of copper with pure and modified chitosan hydrogels from shrimp shell, from copper leachate [37], Saccharomyces cerevisiae and Torulaspora delbrueckii decrease in $98.1 \%, 83.0 \%, 60.7 \%, 60.5 \%$, and $54.2 \%$ for turbidity, sulphates, BOD, phosphates, and COD, respectively, of the tannery effluent [38], C. tropicalis removed $40 \%$ of cadmium (II) from the wastewater after 6 days and was also able to remove $78 \%$ from the wastewater after 12 days [28], and S. cerevisiae "wild-type" (WT) parental strain BY4741, very efficient in removing manganese (II), copper (II), and cobalt (II) from synthetic effluents containing 1-2 mM cations [39]. Industrial effluents often contain more than one type of metal ion; these may interfere in the removal/recovery of the metal ion of interest. Limited information about the effect of cocations is available in the literature. The presence of other cations (cocations) can affect the sorption of metal ions (primary cation) to the biomass, and in some cases, it may affect the removal efficiency [40].

\section{Conclusion}

We isolated a fungus, which was identified such as $A$. niger, which grow with different heavy metals in LMM, and probably is resistant to the metals. The dead fungal biomass removed efficiently different heavy metals (chromium (VI) and zinc (II) (100\%), mercury (II) $(83.2 \%)$, and fluorine (I) $(83 \%))$ at different $\mathrm{pH}$ conditions (4.0 for lead (II), 5.0 for zinc (II), and cobalt (II), and 5.5 for mercury (II)), $28^{\circ} \mathrm{C}$, and $1 \mathrm{~g}$ of fungal biomass. Finally, these results suggest the potential applicability of this fungus for the remediation of heavy metals from polluted soils and waters.

\section{Data Availability}

The figures (graphics) and tables or any information data used to support the findings of this study are included within the article, and all information used to support the findings of this study are available from the corresponding author upon request.

\section{Disclosure}

All the authors of this work transfer any and all rights in and to the paper. Authors represents and warrants that the paper is original and that he/she is the author of the paper, except for material that is clearly identified as to its original source, with permission notices from the copyright owners where required.

\section{Conflicts of Interest}

All authors declare that there are no conflicts of interest.

\section{Acknowledgments}

This research work was carried out without funds from any institution, but nevertheless it was done with the collaboration of Professors of the Autonomous University of San Luis Potosi, the Multidisciplinary Academic Unit Central Zone-UASLP, and the Autonomous University of the State of Hidalgo, where each teacher uses own and particular resources.

\section{References}

[1] L. Albert, "Gestión de los productos químicos," in En: México Tóxico, L. A. Albert and M. Jacott, Eds., pp. 21-37, XXI Siglo veintiuno editores, Mexico, 1st edition, 2015.

[2] J. Zaidi and A. Pal, "Review on heavy metal pollution in major lakes of India: remediation through plants," African Journal of Environmental Science and Technology, vol. 11, no. 6, pp. 255-265, 2017.

[3] I. Mena Mejia, A. Bustamante González, S. Vargas López, J. I. Olvera Hernández, and J. A. Méndez Espinosa, "Evaluación de la condición ecológica del río Zahuapan," Revista Internacional de Contaminación Ambiental, vol. 33, no. 1, pp. 7-19, 2017.

[4] S. A. Covarrubias and J. J. Peña Cabriales, "Contaminación ambiental por metales pesados en México: problemática y estrategias de fitorremediación," Revista Internacional de Contaminación Ambiental, vol. 33, no. 2, pp. 7-21, 2017.

[5] E. V. Cortés-Jiménez, V. Mugica-Álvarez, M. C. GonzálezChávez, R. Carrillo-González, M. Martínez-Gordillo, and M. Vaca-Mier, "Natural revegetation of alkaline tailing heaps at Taxco, Guerrero, Mexico," International Journal of Phytoremediation, vol. 15, pp. 127-141, 2013.

[6] E. Ortíz-Ortíz, E. García-Nieto, L. Juárez-Santacruz, M. A. Gómez-Camarillo, E. García-Gallegos, and P. LimónHuitrón, "Lead exposure: pottery impact in Tlaxcala, México," Revista Internacional de Contaminación Ambiental, vol. 33, no. 1, pp. 57-64, 2017.

[7] Y. R. Ramos-Arroyo and C. D. Siebe-Grabach, "Estrategia para identificar jales con potencial de riesgo ambiental en un distrito minero: estudio de caso en el Distrito de Guanajuato, 
México," Revista Mexicana de Ciencias Geológicas, vol. 23, pp. 54-74, 2006.

[8] SEMARNAT, Norma Oficial Mexicana NOM- 001-SEMARNAT 1996. Que establece los límites máximos permisibles de contaminantes en las descargas de aguas residuales en aguas y bienes nacionales. Secretaría de Medio Ambiente, Recursos Naturales y Pesca. Diario Oficial de la Federación, 2003.

[9] SEMARNAT, Norma Oficial Mexicana. NOM- 147SEMARNAT/SSA1-2004. Que establece los criterios para determinar las concentraciones de remediación de suelos contaminados por arsénico, bario, berilio, cadmio, cromo hexavalente, mercurio, níquel, plata, plomo, selenio, talio y/ o vanadio. Secretaría de Medio Ambiente, Recursos Naturales y Pesca. Diario Oficial de la Federación. 2 de marzo de, 2007.

[10] C. Nava Ruíz and M. Méndez Armenta, "Efectos neurotóxicos de metales pesados (cadmio, plomo, arsénico y talio)," Archivos de Neurociencias (México), vol. 16, no. 3, pp. 140147, 2011.

[11] E. M. Fawzy, F. F. Abdel-Motaal, A. Soad, and S. A. El-Zayat, "Biosorption of heavy metals onto different eco-friendly substrates," Journal of Bioremediation and Biodegradation, vol. 8, no. 3, pp. 1-7, 2017.

[12] J. Yang, Q. Wang, Q. Luo, Q. Wang, and T. Wud, "Biosorption behavior of heavy metals in bioleaching process of MSWI fly ash by Aspergillus niger," Biochemical and Engineering Journal, vol. 46, pp. 294-299, 2009.

[13] A. M. Rivas-Castillo, M. E. Guatemala-Cisneros, and N. G. Rojas-Avelizapa, "Effect of aluminum in Bacillus megaterium nickel resistance and removal capability," Mexican Journal of Biotechnology, vol. 2, no. 2, pp. 206-220, 2017.

[14] S. Grujić, S. Vasić, I. Radojević, L. Čomić, and A. Ostojić, "Comparison of the Rhodotorula mucilaginosa biofilm and planktonic culture on heavy metal susceptibility and removal potential," Water Air Soil Pollution, vol. 228, no. 73, pp. 1-8, 2017.

[15] Y. Jin, S. Yu, C. Teng et al., "Biosorption characteristic of Alcaligenes sp. BAPb.1 for removal of lead (II) from aqueous solution," 3 Biotech, vol. 7, no. 123, pp. 1-12, 2017.

[16] M. G. Moctezuma Zárate, A. Robles Galván, J. F. Cárdenas González et al., "Isolation and identification of fungi and yeast resistant to lead (II)," Journal of Multidisciplinay Engineering Science and Technology, vol. 4, no. 6, pp. 5273-5278, 2017.

[17] I. Acosta-Rodríguez, J. F. Cárdenas-González, M. G. MoctezumaZárate, A. Rodríguez Pérez, and V. M. Martínez-Juárez, "Hexavalent chromium (VI) removal by Aspergillus niger," in MetalMicrobe Interactions and Bioremediation: Principles and Applications for Toxic Metals, pp. 673-688, S. Das, Ed., CRS Press Book, Taylor \& Francis, Boca Raton, FL, USA, 2017.

[18] M. Mukhopadhyay, S. B. Noronha, and G. K. Suraishkumar, "A review on experimental studies of biosorption of heavy metals by Aspergillus niger," Canadian Journal of Chemical Engineering, vol. 89, pp. 889-900, 2011.

[19] A. Kapoor, T. Viraraghavan, and D. R. Cullimore, "Removal of heavy metals using the fungus Aspergillus niger," Bioresource Technology, vol. 70, pp. 95-104, 1999.

[20] K. Tsekova, D. Todorova, and S. Ganeva, "Removal of heavy metals from industrial wastewater by free and immobilized cells of Aspergillus niger," International Biodeterioration and Biodegradation, vol. 64, pp. 447-451, 2010.

[21] I. Acosta-Rodríguez, J. F. Cárdenas-González, V. M. MartínezJuárez, A. Rodríguez Pérez, M. G. Moctezuma-Zárate, and N. C. Pacheco-Castillo, "Biosorption of heavy metals by
Candida albicans," in Advances in Bioremediation and Phytoremediation, N. Shiomi, Ed., INTECH, 2018.

[22] D. Pokhrel and T. Viraraghavan, "Arsenic removal from an aqueous solution by a modified fungal biomass," Water Research, vol. 40, no. 3, pp. 549-552, 2006.

[23] A. E. Greenberg, L. S. Clesceri, and A. D. Eaton, Standard Methods for the Examination of Water and Wastewater, American Public Health Association, Washington, DC, USA, 18th edition, 1992.

[24] G. Charlot, Colorimetric Determination of Elements, Elsevier Publishing Company, Amsterdam, London, 1964.

[25] SEDECO, Directorio de empresas que operan en las zonas y parques industriales de la ciudad de San Luis Potosí, Secretaría de Desarrollo Económico, San Luis Potosí, México, 2014.

[26] M. P. Kirk, F. P. Cannon, C. J. David, and A. J. Stalpers, Dictionary of the fungi, CABI Publishing, UK, 2001.

[27] M. Valix and L. O. Loon, "Adaptive tolerance behavior of fungi in heavy metals," Mineral Engineering, vol. 16, pp. 193-198, 2003.

[28] A. Rehman and M. S. Anjum, "Multiple metal tolerance and biosorption of cadmium by Candida tropicalis isolated from industrial effluents: glutathione as detoxifying agent," Environmental Monitoring Assessment, vol. 174, pp. 585-595, 2011.

[29] Y. G. Liu, T. Fan, G. M. Zeng et al., "Removal of cadmium and zinc ions from aqueous solution by living Aspergillus niger," Transactions of Nonferrous Metals Society of China, vol. 16, pp. 681-686, 2006.

[30] R. Vadkertiova and E. Slavikova, "Metal tolerance of yeasts isolated from water, soil and plant environments," Journal of Basic Microbiology, vol. 46, pp. 145-152, 2006.

[31] N. G. Rojas-Avelizapa, J. Otamendi-Valdez, and M. GómezRamírez, "Metal leaching from a spent catalyst by Alternaria alternata," Mexican Journal of Biotechnology, vol. 2, no. 2, pp. 221-231, 2017.

[32] A. Ali, G. Di, A. Mahar et al., "Mycoremediation of potentially toxic trace elements. A biological tool for soil cleanup: a review," Pedosphere, vol. 27, no. 2, pp. 205-222, 2017.

[33] M. Beltrán and A. Gómez, "Metales pesados (Cd, Cr y Hg) su impacto en el ambiente y posibles estrategias biotecnológicas para su remediación," Revista I3+, vol. 2, no. 2, pp. 82-112, 2015.

[34] L. F. Sala, S. I. García, J. C. González et al., "Biosorción para la eliminación de metales pesados en aguas de desecho," Real Sociedad Española Química, vol. 106, no. 2, pp. 114-120, 2010.

[35] A. Aragon, B. Thomson, and J. Chwirka, Rapid Small-Scale Column Testing for Arsenic Adsorption, 2004, http://ipec. utulsa.edu/lpec/conf2002/aragon_thomson_chwirka_50.pdf.

[36] E. E. Santos Domínguez, J. F. Cárdenas, M. E. Torre, V. M. Martínez, A. Rodríguez, and E. I. Acosta, "Bioadsorción de Arsénico (III) en solución acuosa por la Biomasa Modificada de Aspergillus niger," Avances en Ciencias e Ingeniería, vol. 8, no. 2, pp. 1-10, 2017.

[37] R. G. Sánchez-Duarte, M. R. Martínez-Macias, M. A. CorreaMurrieta, J. Saldival-Cabrales, D. I. Sánchez-Machado, and J. López-Cervantes, "Síntesis de hidrogeles de quitosano a partir de cáscara de camarón para ensayos de bioadsorción de cobre," Revista Internacional de Contaminación Ambiental, vol. 33, pp. 93-98, 2017.

[38] M. L. Nguyen and J. Ruey-Shin, "Modification of cross linked chitosan beads with histidine and Saccharomyces cerevisiae for enhanced $\mathrm{Ni}(\mathrm{II})$ biosorption," Journal of Taiwan Institute of Chemical Engineering, vol. 56, pp. 96-102, 2015.

[39] L. Ruta, C. Paraschivescu, M. Matache, S. Avramescu, and I. C. Farcasanu, "Removing heavy metals from synthetic 
effluents using "kamikaze" Saccharomyces cerevisiae cells," Applied Microbiology and Biotechnology, vol. 85, pp. 763-771, 2010.

[40] M. J. Tobin, D. G. Cooper, and R. J. Neufeld, "The effects of cation competition on metal adsorption by Rhizopus arrhizus biomass," Biotechnology and Bioengineering, vol. 31, pp. 282-286, 1988. 

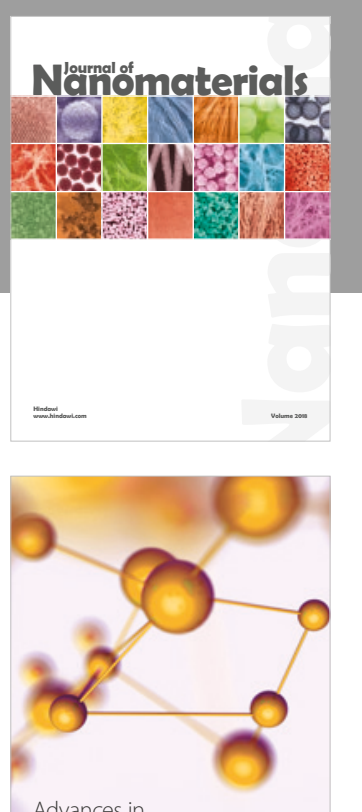

Physical Chemistry
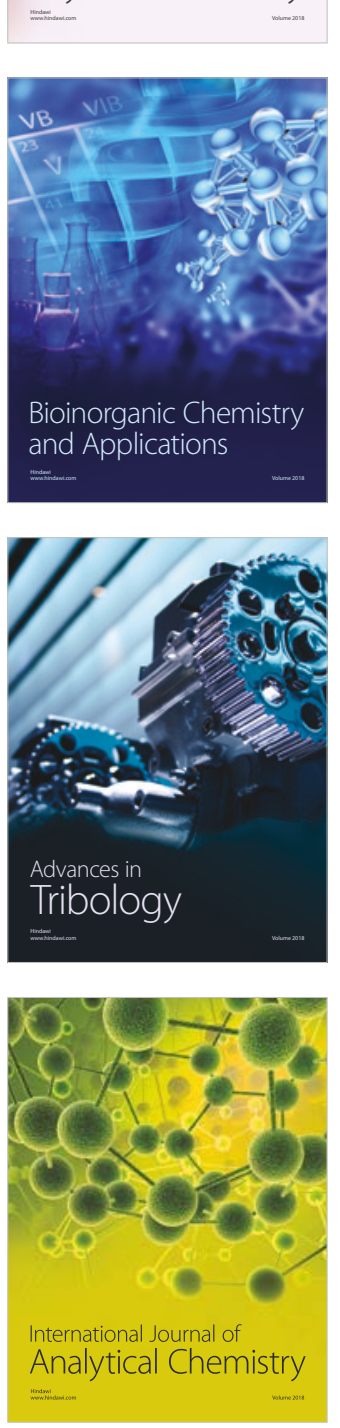

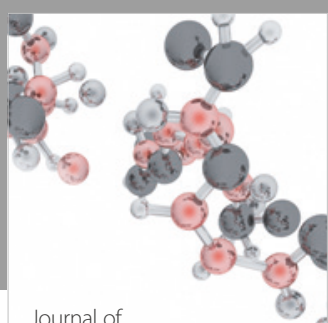

Analytical Methods

in Chemistry

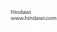

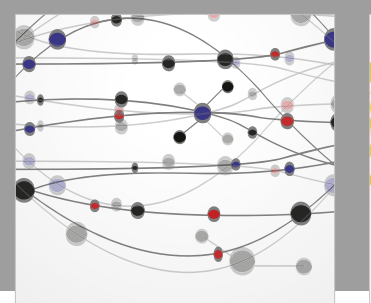

The Scientific World Journal

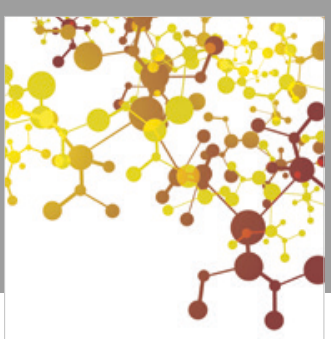

Journal of

Applied Chemistry
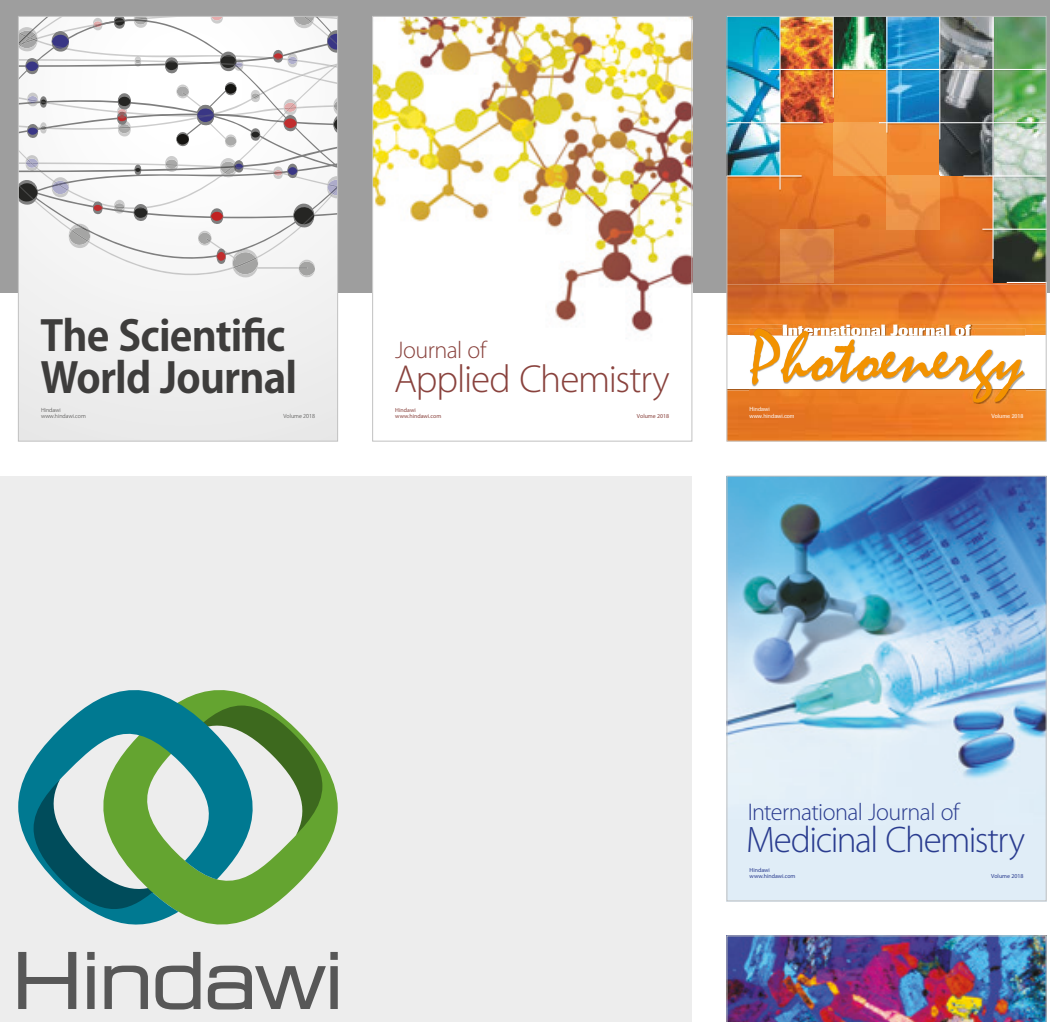

Submit your manuscripts at

www.hindawi.com
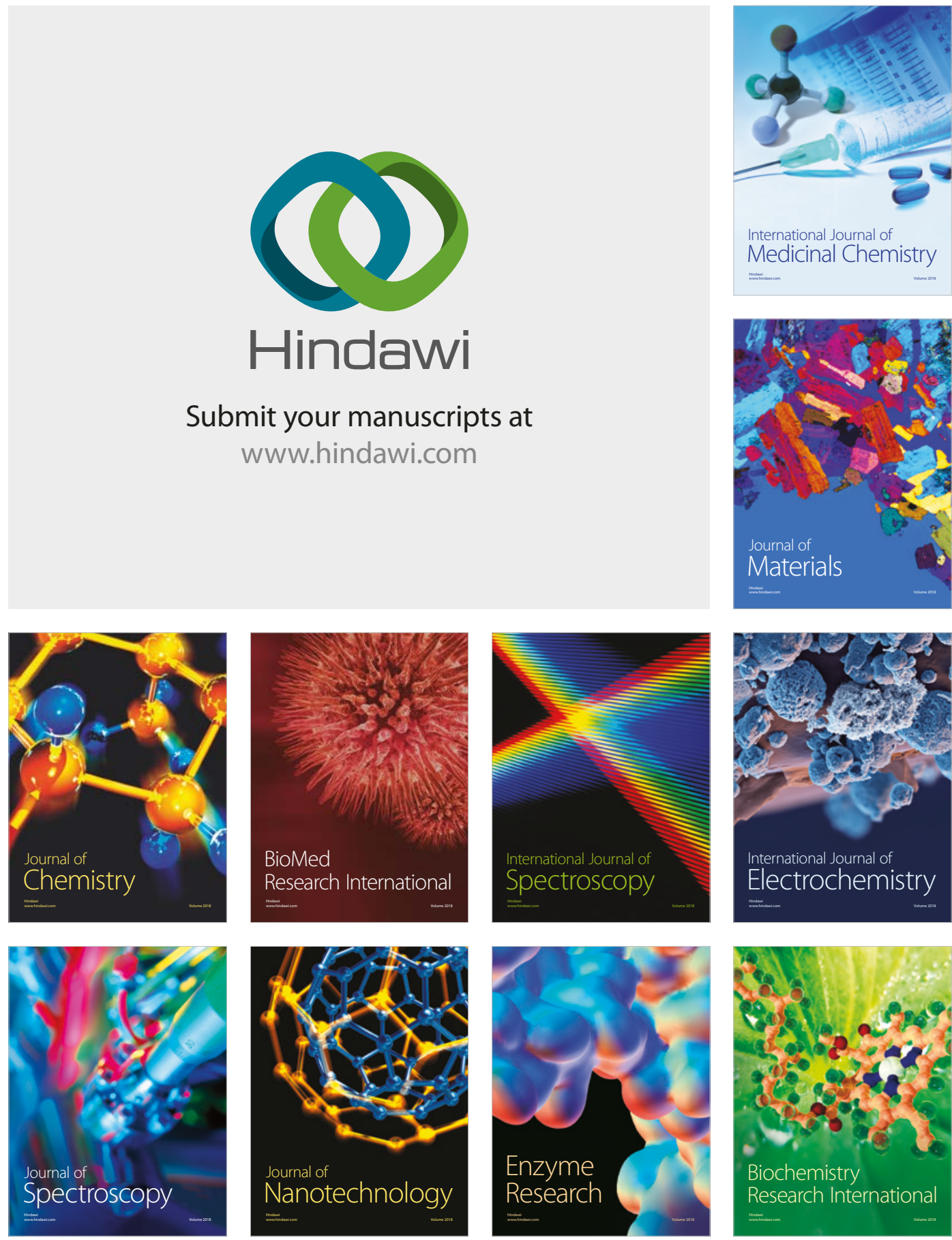
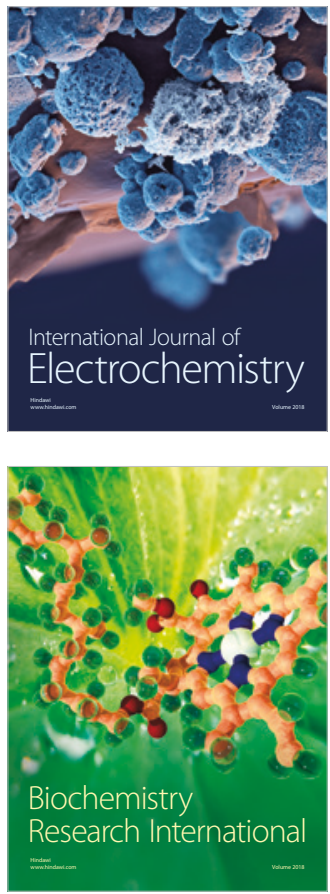